\title{
CONTEXTUAL TEACHING AND LEARNING IN LEARNING ENVIRONMENTAL POLLUTION: THE EFFECT ON STUDENT LEARNING OUTCOMES
}

\author{
Ria C. Welerubun ${ }^{1}$, Hengky L.Wambrauw ${ }^{2}$, Jeni Jeni' ${ }^{3 *}$, Daniel Wolo ${ }^{4}$, Insar Damopolii ${ }^{5}$ \\ 1,2,3,5 Universitas Papua, Manokwari, Indonesia \\ ${ }^{4}$ Universitas Flores, Ende, Indonesia \\ *Corresponding Author: $\otimes$ j.jeni@unipa.ac.id
}

\begin{tabular}{l} 
Info Artikel \\
\hline Sejarah Artikel: \\
Diterima:20/12/2021 \\
Direvisi : 26/12/2021 \\
Disetujui:30/12/2021 \\
\hline Keywords: \\
CTL, Biology, Learning \\
outcomes, Environmental \\
pollution, Learner \\
\hline
\end{tabular}

Kata Kunci:

CTL, Biologi, Hasil belajar, Pencemaran lingkungan, Pembelajar

\begin{abstract}
Contextual Teaching and Learning (CTL) is a learning concept helps teachers relate subject concepts to real-world situations and student engagement to find materials learned and connect in everyday life. This study aims to determine the influence of CTL to improve student learning outcomes on environmental pollution materials during pandemics. The research was conducted at Manokwari Advent Junior High School in April-May 2021. The sample of learning grade VII A (experimental class) number of learners as many as 22 people and grade VII B (control class) the number of learners 20 people. This research method was quasi-experimentation with a nonequivalent control group design, an instrument used in research in the form of cognitive tests in the form of multiple choice. Analysis of data mechanisms used in the study was a normality test, homogeneity testing, and followed by hypothesis testing using the SPSS IMB 20 mentoring program. After the test was obtained, the results of the learning class experimental have an average post-test of 86.25 , while the value of the post-test control class is 45.25 ; then, it can be concluded that the CTL model can improve the learner learning outcomes.
\end{abstract}

Abstrak. Contextual Teaching and Learning (CTL) adalah konsep pembelajaran yang membantu guru menghubungkan konsep mata pelajaran dengan situasi dunia nyata dan keterlibatan siswa untuk menemukan materi yang dipelajari dan menghubungkannya dalam kehidupan sehari-hari. Penelitian ini bertujuan untuk mengetahui pengaruh CTL terhadap peningkatan hasil belajar siswa pada materi pencemaran lingkungan pada masa pandemi. Penelitian dilaksanakan di SMP Advent Manokwari pada bulan April-Mei 2021. Sampel pembelajaran kelas VII A (kelas eksperimen) jumlah peserta didik sebanyak 22 orang dan kelas VII B (kelas kontrol) jumlah peserta didik 20 orang. Metode penelitian ini adalah quasi-experimentation dengan nonequivalent control group design, instrumen yang digunakan dalam penelitian berupa tes kognitif berupa pilihan ganda. Mekanisme analisis data yang digunakan dalam penelitian adalah uji normalitas, uji homogenitas, dan dilanjutkan dengan uji hipotesis menggunakan program pendampingan SPSS IMB 20. Setelah tes diperoleh, hasil belajar kelas eksperimen memiliki rata-rata post-test 86,25, sedangkan nilai post-test kelas kontrol adalah 45,25; maka, dapat disimpulkan bahwa model CTL dapat meningkatkan hasil belajar peserta didik.

How to Cite: Welerubun, R. C., Wambrauw, H. L., Jeni, J., Wolo, D., \& Damopolii, I. (2022). CONTEXTUAL TEACHING AND LEARNING IN LEARNING ENVIRONMENTAL POLLUTION: THE EFFECT ON STUDENT LEARNING OUTCOMES. Prima Magistra: Jurnal Ilmiah Kependidikan, 3(1), 106-115. https://doi.org/10.37478/jpm.v3i1.1487

\begin{tabular}{ll}
\hline Alamat korespondensi: & Penerbit: \\
Jl. Gunung Salju, Kelurhan Amban, Kecamatan Manokwari & Program Studi PGSD Universitas Flores. \\
Barat, Manokwari, Papua Barat. 98314 & orimagistrauniflor@ gmail.com
\end{tabular}

, 98314

$\otimes$ primagistrauniflor@gmail.com 


\section{INTRODUCTION}

COVID poses a variety of threats to learning. In the COVID period, there are problems with student learning outcomes (Damopolii, Lumembang, \& İlhan, 2021; Raiman, Liu, \& Wolo, 2021). Learning must run even if the conditions do not vary (Chandio, 2021). Schools were closed during the pandemic, but learning was changed to online mode (Bailey et al., 2021; Chaturvedi, Purohit, \& Verma, 2021; Engzell, Frey, \& Verhagen, 2021; Merfeldaite, Lent, \& Railiene, 2020). Learning and instruction are two things that go hand in hand and can't be separated from each other in educational programs.

Learning and instruction are said to be a model of education because there is a relationship between the educator and the learner (Djaguna et al., 2021; Lelasari, Yohanita, \& Damopolii, 2021; Mandasari, Iwan, \& Damopolii, 2021). Teaching and learning activities are designed to help students accomplish certain objectives that have been established before any teaching takes place. Teachers intentionally prepare to teach activities in a methodical manner, making use of everything available to them for learning (Pane \& Dasopang, 2017).

According to Rusman (2010), the learning model is the pattern of choice to improve learning outcomes. That is, teachers can determine relevant and efficient learning models to achieve learning goals. The types of learning in teaching include the CTL is an abbreviation for contextual teaching and learning (Ruto et al., 2021), cooperative learning (Werimon, Damopolii, \& Nunaki, 2017), and problem-based learning (Damopolii \& Kurniadi, 2019), and inquiry (Aco, Rahman, \& Firman, 2021). Focusing on CTL, this learning provides a real-life experience to learning and allows it to be applied in pandemic conditions.

CTL is a concept of education that teachers implement by presenting real-world situations in the classroom and encouraging learners to make associations between their acquired knowledge and its application in life, while students acquire knowledge through experience or the process of self- construction (Novita, Hodijah, \& Taufik, 2022). This learning concept aims to train learners to solve problems in the process of their lives as a provision to solve problems in their lives. CTL is learning that connects material with real-life so that learners can connect and apply the competence of learning outcomes in everyday life (Zulaiha, 2016).

According to Ismail (2017), the CTL model uses CTL learning occurs when learners practice and gain experience with what is being taught by referring to the material discussed. Students' knowledge and skills are gained from the efforts of learners to apply ideas taught by teachers in the form of demonstrations and practicums. The process of linking concepts into real-life makes learners interested in learning the material delivered.

The CTL model is a learning model that helps teachers be able to directly provide examples that exist in the environment around learners in their daily lives. Learners are also required to be able to think based on their observations around the environment. Thus, the selection of the right CTL can help learners to be more comprehensible of the material presented by their teachers (Bhure et al., 2021; Ruto et al., 2021).

Biology is one part of the Natural Sciences (NS) that studies natural phenomena, both living and nonliving. In addition to providing education to learners, the field of biological sciences is also one of the domains to foster the ability to think and solve problems in everyday life. In connection with the state of the COVID-19 pandemic to date, instruction and learning activities still use the system in the network / online. Teachers often only convey biological learning materials in the form of information, and then learners only listen. The activity of learners who only listen from teachers is lacking in developing learners' thinking skills so that it greatly affects the learning outcomes of learners. The ability to think is very important in a learning activity because it is able to equip learners in overcoming problems in the midst of the competition of the globalization era as it is 
today. Learning that does not involve learners makes learners tend to be passive and lazy to learn so as not to listen to the teacher's explanation well.

Based on the experience of researchers for \pm two months carrying out the Introduction of School Field (Perkenalan lingkungan persekolahan-PLP) during the Covid-19 pandemic at Manokwari Adventist Junior High School, teaching and learning activities took place online using zoom media. Biological learning is the provision of hands-on experience. Therefore, learners need to be helped to develop a number of process skills so that learners are able to explore and understand the environment. Based on this fact, it is seen that some learners consider biology subjects as rote lessons because, in the learning process, learners are more likely to listen to lectures from teachers. Teachers must be able to choose a model that is in accordance with the material taught and have an interesting way of teaching to obtain high learners' learning outcomes.

The reality on the ground is seen, that teachers only focus on one model, namely lectures, giving fewer examples of material concepts that are below in everyday life for learners, so that sometimes learners become bored, the activeness of learners decreases because learners listen more often than observe the surroundings and connect them with theoretical concepts. This is seen in the results of the Midterm Examination, especially biology subjects, followed by 28 learners with minimum completion criteria (MCC) standards of 70. Uts value range of biology subjects obtained by learners between 65-80. If based on MCC standards, there are 15 learners who achieve grades below MCC.

A number of learning models can be implemented as an effort to increase motivation that influences the learning outcomes of learners. One suitable learning to instruction is the CTL. The application of the CTL is expected to create an interesting atmosphere in learning so that learners' learning activities are more meaningful. The application of CTL can stimulate learners to be more active and have a deeper curiosity about biology lessons, especially in environmental pollution materials (Laili, 2021; Ritonga, 2016).

An environmental pollution is an event that occurs directly within the scope of real life. Thus, researchers use environmental pollution materials as teaching materials in this study so that they can be directly related to the use of CTL. The use of the CTL in environmental pollution materials can invite learners to observe the situation in the surrounding environment directly.

The CTL model can be used in learning because the material taught can be connected to real life. Contextual learning presents real conditions that support students' thinking development and the quality of their learning (Hernáiz-Pérez et al., 2021). The CTL model can also provide a pleasant, more active learning atmosphere because it can directly observe the surrounding environment and improve learners' learning outcomes. According to Darmawan (2013), that CTL can make it easier for learners to absorb the subject matter, and learners are more active in thinking and understanding the material. This is in line with the view according to Ismail (2017), judging from the advantages of the CTL model, namely teaching centered on learners, making learners more active, teachers can monitor and direct learners, so that learners get more meaningful learning.

Based on the above facts, there needs to be a change in learning strategy from teacher-centered to student-centered. Learncentered learning is learning that is more focused on the needs, interests, talents, and abilities of learners so that learning is more meaningful. So researchers see it is very suitable if used the CTL model, which is one of the learning models centered on learners. The purpose of this study is to find out the influence of CTL models on improving learners' learning outcomes in environmental pollution materials of class VII Adventist Manokwari Junior High School in the pandemic period. 


\section{METHODS}

This research was carried out at Manokwari Adventist Junior High School and was designated as a quasi-experimental study. The participants in this research belonged to the seventh grade. Students from class VII A, who served as the experimental class, and students from class VII B, who served as the control class, participated in the research. This model was applied to both the experimental group and the control group. The experimental group was given treatment, but the control group was utilized as a comparative class and did not get treatment with the CTL learning model. The findings of this research are provided in text form, with the data being presented in a quantitative format. Techniques for data collecting are used both before and after the exam. The learning outcomes may be seen in both the experimental and control classrooms after the post-test.

The sample used by researchers in this study consists of 2 groups, namely:

a. The experimental group, taken from a group of students who used a learning model using the CTL model. The sample selected as a group in this study was a class VII A participant who numbered 28 learners.

b. The Control group was taken from a group of students who used a conventional learning model. The sample selected as a group in this study were class VII B students who numbered 28 learners.

Research in the early stages of the pretest is done through multiple-choice tests carried out at the beginning of the learning process. The test is in the form of a problem in the form of multiple-choice (multiple choice), which amounted to 20 questions. Furthermore, learning is carried out by applying the CTL learning model. Implementation of distance learning innetwork and off-network. This is done because there are still some learners who are constrained by supporting devices for the implementation of learning, so that those who are present in the learning activities of 16 learners (online) and outside the network of 6 learners with a total of 22 learners (total students 28 but 6 do not follow the learning) class VII-A. Similar to class VII-B learning activities, students who attended the network amounted to 15 and 5 out-of-network learners with the overall number of class VII B 20 (total students 28 but 8 did not follow the learning) learners using conventional learning models.

The form of implementation of the distance learning process in the network is the teacher first prepares a WhatsApp group as a medium of interaction between learners and teachers. Aspects coordinated in WhatsApp groups in the form of learning schedules, assignments, and readiness of learners in participating in learning activities. The learning process outside the network for learners who are constrained by online learning devices is teachers doing face-to-face teaching. Technically every session 2 , learners take turns using health protocols.

The learning process at the second and third meetings is still carried out using learning models (CTL) and conventional as learning is done at the first meeting. However, the third meeting held post-test after the end of learning activities in the classroom. The data obtained was recapitulated and then analyzed to find out the effect of the use of CTL on learning outcomes in IPA subjects of environmental pollution materials in Manokwari Adventist Junior High School.

After testing the instrument, the data analysis technique is then carried out. The data collected through research instruments are examined and calculated with the purpose of offering answers to research questions via the hypothesis testing procedure. Data analysis is in the form of data normality, $t$ paired test (seeing improvements in learning outcomes in each class), and independent $t-$ test (to see differences in learning outcomes in both classes).

\section{RESULTS AND DISCUSSION}

The results of a study in an experimental class using the CTL model as a learning model are shown in Table 1. 
Table 1. Result of experimental class

\begin{tabular}{ccc}
\hline Statistics & \multicolumn{2}{c}{ Class VIIA } \\
& (Exsperimental) \\
\cline { 2 - 3 } & Pre-Test & Post-Test \\
\hline Lots of data & 22 & 22 \\
Lowest Score & 20 & 75 \\
High Score & 55 & 100 \\
Mean & 35.50 & 86.25 \\
Median & 35.00 & 85.00 \\
Modus & 30.0 & 75.0
\end{tabular}

Defferent Mean $=\mathbf{2 0 . 2 7 4}$

Based on Table 1 above, the post-test of 22 respondents obtained the highest score of the experimental class was 100, and the lowest score was 75; the average was 86.25. The results of a study in a control class that used the conventional model (lecture) as a learning model, shown in Table 2.
Based on table 2, of the 20 respondents using conventional learning models in the control class, the highest score was 70, and the lowest was 45. The average was 45.25. There are differences in the findings of student learning outcomes in the experimental and control classes.

Table 2. Result of control class

\begin{tabular}{ccc}
\hline Statistics & \multicolumn{2}{c}{ Class VIIB (Control) } \\
\cline { 2 - 3 } & Pre-Test & Post-Test \\
\hline Lots of data & 20 & 20 \\
Lowest Score & 25 & 45 \\
High Score & 45 & 70 \\
Mean & 35.25 & 45.25 \\
Median & 35.00 & 52.50 \\
Modus & 30 & 50 \\
Defferent Mean $=\mathbf{1 6 . 8 1 4}$ & \\
\hline
\end{tabular}

Table 3. Result of normality

\begin{tabular}{cccccc}
\hline No & Aspect & Df & Group & Sig. & Decision \\
\hline 1. & Pre-test & 22 & Experimental & 0.130 & Normally \\
2. & Post-test & 22 & Experimental & 0.82 & Normally \\
3. & Pre-test & 20 & Control & 0.59 & Normally \\
4. & Post-test & 20 & Control & 0.60 & Normally \\
\hline
\end{tabular}

The results of the normality test with Kolmogorov Smirnov test above that the probability of t-statistics $>$ Significant Level $=$ 0.05 , then the data meets the assumption of normality. Table 4.3 shows the pre-test score in the experimental class obtained sig $0.130>$ 0.05 , so ho was accepted, and $\mathrm{Ha}$ was rejected. This means that there is no deviation from normality or normally distributed data. The post-test score in the experimental class obtained sig $0.82>0.05$ so that the data were distributed normally. At the same time, the pre-test data of the control group obtained sig $0.59>0.05$, so that the data is said to be a normal distribution. The control class post-test data obtained a sig result of $0.60>0.05$ so that Ho was accepted and $\mathrm{Ha}$ was rejected; then, it can be said that the post-test data is the normal distribution.

Testing groups of learners who get treatment with the CTL model (experimental class) in the learning process have a higher mean score compared to the group of learners with a lecture / conventional model (control class). Here are the results of different tests of control class learners who took the t-test.
Table 4. Pre-test and pos-test (experimental)

\begin{tabular}{ccc}
\hline Variable & $\mathbf{t}$ & Sig \\
\hline $\begin{array}{c}\text { Pret-test and Post- } \\
\text { test }\end{array}$ & -21.759 & 0.000 \\
& $\mathbf{N}=\mathbf{2 2}$ & \\
\hline
\end{tabular}

Based on the Paired samples t-test table 4, the t-test sample obtained significance of 0.000 less than the significant level $(\alpha)=0.05$, then Ho was rejected. This indicates that there is a statistically significant difference between the mean value before therapy and the average value after treatment, as shown in the table. In the table, a negative t-count (-21.759) indicates that the average before treatment is lower than the average after treatment is completed and that the outcomes of learning control classes improve from pre-test to post-test as a consequence of the treatment.

Testing groups of learners who get CTL model treatment (experimental class learners) in the learning process have higher scores than the group of learners without the CTL model. The following are the results of different tests of experimental class learners using the t-test. 
Table 5. Pre-test and post-test (control)

\begin{tabular}{ccc}
\hline Variable & $\mathbf{t}$ & Sig \\
\hline $\begin{array}{c}\text { Pret-test and Post- } \\
\text { test }\end{array}$ & -10.156 & 0.000 \\
& $\mathbf{N}=\mathbf{2 0}$ & \\
\hline
\end{tabular}

Ho was rejected based on the results of significant level of 0.000 less than 0.05 . This indicates that the average value before therapy and the average value after treatment are significantly different. According to the t-table, the average before treatment is lower than the average after treatment (-10.156). table 5 paired sample t-test, which showed a

Table 6. Homogeneity and t-test independent result

\begin{tabular}{rlcccccc}
\hline & Data & F & Sig. & t & df & P & $\begin{array}{c}\text { Mean } \\
\text { Difference }\end{array}$ \\
\hline \multirow{3}{*}{ Pre } & $\begin{array}{l}\text { Equal variances } \\
\text { assumed }\end{array}$ & 0.854 & 0.361 & 0.468 & 40 & 0.642 & 1.34091 \\
& $\begin{array}{l}\text { Equal variances } \\
\text { not assumed } \\
\text { Equal variances } \\
\text { Post }\end{array}$ & 1.669 & 0.204 & 10.939 & 40 & 0.000 & 31.88636 \\
& $\begin{array}{l}\text { assumed } \\
\text { Equal variances } \\
\text { not assumed }\end{array}$ & & & 11.024 & 39.853 & 0.000 & 31.88636 \\
\hline
\end{tabular}

This study aims to find out the influence of contextual teaching and learning (CTL) models on improving learners' learning outcomes in environmental pollution materials of class VII Adventist Manokwari junior high school in the pandemic period.

The CTL model encourages learners to know something or get information and provides a view of learners about various things seen and felt around the environment, then connects it with every theory concept taught. According to Mauke et al. (2013), CTL is able to foster the ability to understand concepts and problemsolving skills in the learning process, learning activities based on learners' real experiences, and directed learning processes by linking concepts or theories that consider the experiences of learners and students. Their living environment. Same with that question. CTL in biological learning provides empirical evidence to improve and encourage student performance (Suryawati, Osman, \& Meerah, 2010).

Based on the results obtained by researchers, the high increase in learners' learning outcomes in experimental classes and the magnitude of the average increase in learners' learning outcomes before and after learning using the CTL model is due to learning that uses the CTL model emphasizes the process of full student engagement linking learning with reallife in Rill, this is in line with the Hakim, Sururuddin, \& Haqiqi (2021), learners experience an increase in learning outcomes, teachers conduct learning activities in class with the CTL model in providing examples of contextual, learners are more active in explaining the knowledge they have with the material presented by teachers.

Based on the results of learning analysis using CTL learning models, learning has good effectiveness than learning using the convention model (lecture). This effectiveness can be seen from the learning outcomes of learners who use the CTL model to achieve great improvement. It is also supported by Syaifuddin, Nurlaela, \& Perdana (2021), student learning results increased by $7 \%$ from prior conditions, Herawaty \& Widada (2018), problem-solving skills and ability to improve concepts when students are involved in CTL, and Hyun et al. (2020) found that the concept of Korean students in Indonesia can be improved through CTL.

Research by Dewi \& Primayana (2019) on the influence of CTL on the cultivation of student concepts found that in the experimental classroom more effective than learning in the control group. In line with Mustamu (2018) shows that learners who use the CTL model are better than learning without using CTL. Learners have a high interest in the learning process judging by the positive response of learners to CTL learning.

The increase in learners' learning outcomes is due to learners being passionate in learning activities so as to connect the material with the surrounding circumstances. Suwarni et al. (2013) argue that CTL learning allows for communicative social interaction to make learning effective in achieving the learning goals 
of participants who are able to relate the experience they already have with learning that causes understanding of concepts to be well understood.

According to Darmawan (2013), the contextual application is intended to drive students to comprehend the significance of the subject matter they are learning. The content is linked to the learners' own experiences in order for them to gain information or skills that may be applied to a variety of different problems in their daily lives. CTL learning teaching and learning activities can facilitate learners in absorbing the subject matter and strengthen understanding of the amount of subject matter.

The CTL model is a learning principle that prioritizes the learning process and finds knowledge itself and not the redirect of knowledge from the teacher; the learner asks about the material presented by the teacher so that the teacher can provide contextual examples by connecting the real-life-learners. Students' learning resources are their learning experiences that are arranged by the teacher during learning. Teachers can provide many opportunities to their students to make the experience fit the needs of students and the impact of making the student activities. The activity is authentic (Raab \& Bogner, 2021).

This research has been tried and conducted in accordance with scientific procedures, but nevertheless, it still has a border that is the sample taken for research only mostly, namely 22 learners out of the total number of learners is 28 because some learners are not active in the learning process since the government policy related to online learning.

\section{CONCLUSIONS AND SUGGESTIONS}

In light of the findings of the study and the discussion that followed, it can be concluded that CTL has an impact on learners' learning outcomes when it comes to environmental pollution materials at Manokwari Adventist Junior High School.

The results of the study that there was an encouraging in learning outcomes by using the CTL learning model in the subjects of environmental pollution material IPA in Manokwari Adventist Junior High School, the learning outcomes of learners in higher experimental classes were cooled by the control class, hereby proving that the CTL model of learners can be able to provide a view to learners about what is seen and felt around the environment and then connect it with the Every material taught.

The Learning CTL model of teachers encourages learners to know something or get information so that learners produce findings obtained themselves so that learning using contextual teaching and learning models is proven to improve learners' learning outcomes. The results of this study can also be used as references in further research to improve learners' learning outcomes in science learning.

Based on the research results, the research suggests that process learn to teach online, teachers should be more active in checking learners in the learning process from home. The use of learning models, should teachers choose a model that is in accordance with the material presented so that learning is interesting and learners can be able to understand the material presented.

\section{REFERENCES}

Aco, S. N., Rahman, S. R., \& Firman, F. (2021). Using inquiry-based learning to strengthen student learning outcomes. Journal of Research in Instructional, 1(1), 1-12. https://doi.org/doi.org/10.30862/jri.v1i1.2

Bailey, D. H., Duncan, G. J., Murnane, R. J., \& Au Yeung, N. (2021). Achievement gaps in the wake of COVID-19. Educational Researcher, 50(5), 266-275. https://doi.org/10.3102/0013189X211011 237

Bhure, M., Welu, F., See, S., \& Ota, M. K. (2021). The effort to enhance pupils cognitive learning achievement using contextual teaching and learning approach. Journal of Research in Instructional, 1(1), 13-22. https://doi.org/10.30862/jri.v1i1.3

Chandio, A. R. (2021). Evaluating ICT utilization in education administration and management during the COVID-19 outbreak in Pakistan: An empirical 
review. Journal of Research in Instructional, 1(2), 81-94. https://doi.org/10.30862/jri.v1i2.15

Chaturvedi, S., Purohit, S., \& Verma, M. (2021). Effective Teaching Practices for Success During COVID 19 Pandemic: Towards Phygital Learning. Frontiers in Education, $\quad 6, \quad 1-10$. https://doi.org/10.3389/feduc.2021.64655 7

Damopolii, I., \& Kurniadi, B. (2019). The Development of Android-based Mobile Learning Supported by Problem-based Learning Strategy for Students' Learning Success. Int. J. Sci. Technol. Res, 8(7), 190-193. Google Scholar

Damopolii, I., Lumembang, T., \& İlhan, G. O. (2021). Digital Comics in Online Learning During COVID-19: Its Effect on Student Cognitive Learning Outcomes. International Journal of Interactive Mobile Technologies (IJIM), 15(19), 33-47. https://doi.org/10.3991/ijim.v15i19.2339 5

Darmawan, W. (2013). Penerapan CTL untuk meningkatkan hasil belajar biologi siswa SMP/MTs kelas VII pada konsep pencemarab lingkungan (Penelitian tindakan kelas di MTs Al Khairiyah Tajur Citeureup) (Skripsi tidak diterbitkan, Universitas Islam Negeri Syarif Hidayatullah). Skripsi tidak diterbitkan, Universitas Islam Negeri Syarif Hidayatullah. Retrieved from https://repository.uinjkt.ac.id/dspace/bitst ream/123456789/24696/1/Wawan

Darmawan.pdf

Dewi, P. Y. A., \& Primayana, K. H. (2019). Effect of Learning Module with Setting Contextual Teaching and Learning to Increase the Understanding of Concepts. International Journal of Education and Learning, $\quad 1(1), \quad 19-26$. https://doi.org/10.31763/ijele.v1i1.26

Djaguna, F., Langasa, I. A., Husain, B., \& Swara, M. M. (2021). Teacher responses of inserting role-playing strategy in EFL classroom. Journal of Research in
Instructional, $\quad 1(2), \quad 71-80$. https://doi.org/10.30862/jri.v1i2.18

Engzell, P., Frey, A., \& Verhagen, M. D. (2021). Learning loss due to school closures during the COVID-19 pandemic. Proceedings of the National Academy of Sciences, 118(17), e2022376118. https://doi.org/10.1073/pnas.2022376118

Hakim, A. R., Sururuddin, M., \& Haqiqi, N. (2021). Efektivitas pendekatan science environment technology and society berbasis CTL terhadap hasil belajar. Prima Magistra: Jurnal Ilmiah Kependidikan, 2(1), 140-148. https://doi.org/10.37478/jpm.v2i1.901

Herawaty, D., \& Widada, W. (2018). The Influence of Contextual Learning Models and the Cognitive Conflict to Understand Mathematical Concepts and Problems Solving Abilities. Proceedings of the 1st Annual International Conference on Mathematics, Science, and Education (ICoMSE 2017). Paris, France: Atlantis Press. https://doi.org/10.2991/icomse17.2018.17

Hernáiz-Pérez, M., Álvarez-Hornos, J., Badia, J. D., Giménez, J. B., Robles, Á., Ruano, V., \& San-Valero, P. (2021). Contextualized project-based learning for training chemical engineers in graphic expression. Education for Chemical Engineers, 34, 57-67. https://doi.org/10.1016/j.ece.2020.11.003

Hyun, C. C., Wijayanti, L. M., Asbari, M., Purwanto, A., Santoso, P. B., Wardani, I., Bernarto, I., \& Pramono, R. (2020). Implementation of Contextual Teaching and Learning (CTL) to Improve the Concept and Practice of Love for FaithLearning Integration. International Journal of Control and Automation, 13(1), 365-383. Retrieved from http://sersc.org/journals/index.php/IJCA/ article/view/5737

Ismail, I. (2017). Penerapan Model Pembelajaran Contextual Teaching And Learning (CTL) Untuk Meningkatkan Hasil Belajar Siswa Kelas VIII Pada Materi Gerak Lurus Di SMPN 2 Banda Aceh (Skripsi tidak diterbitkan, 
Universitas Islam Negeri Ar-Raniry). Skripsi tidak diterbitkan, Universitas Islam Negeri Ar-Raniry. Retrieved from https://repository.ar-

raniry.ac.id/id/eprint/2241/1/ismail gabung.pdf

Laili, I. (2021). Validitas LKPD Pencemaran Lingkungan Berbasis Contextual Teaching and Learning (CTL) untuk Melatihkan Keterampilan Berpikir Kritis. BioEdu, 10(1). https://ejournal.unesa.ac.id/index.php/bio edu/article/view/36806

Lelasari, T., Yohanita, A. M., \& Damopolii, I. (2021). Effect of inquiry science learning on students' metacognitive skill. Journal of Research in Instructional, 1(1), 53-60. https://doi.org/10.30862/jri.v1i1.12

Mandasari, F., Iwan, I., \& Damopolii, I. (2021). The relationship between science process skills and biology learning outcome. Journal of Research in Instructional, $\quad 1(1), \quad 23-32$. https://doi.org/10.30862/jri.v1i1.9

Mauke, M., Sadia, I. W., \& Suastra, W. (2013). Pengaruh Model Contextual Teaching and Learning Terhadap Pemahaman Konsep dan Kemampuan Pemecahan Masalah dalam Pembelajaran IPA-Fisika di MTs Negeri Negara. Jurnal Pendidikanm Dan Pembelajaran IPA Indonesia, 3(2), 1-12. Retrieved from https://ejournalpasca.undiksha.ac.id/index.php/jurnal_ip a/article/view/796/581

Merfeldaitè, O., Prakapas, R., \& Railienè, A. (2020). Challenges of distance teaching during covid-19: The experience of general education schools. Pedagogika, 140(4), 5-17. https://doi.org/10.15823/p.2020.140.1

Mustamu, B. (2018). Penerapan Model Pembelajaran Contextual Teaching And Learning dengan Pendekatan Tim Ahli Untuk Meningkatkan Hasil Belajar Siswa. Jurnal Bimbingan Dan Konseling Terapan, 2(2), 197-210. https://doi.org/10.30598/jbkt.v2i2.382
Novita, Hodijah, S. R. N., \& Taufik, A. N. (2022). Pengembangan LKPD Berbasis Pendekatan Contextual Teaching Learning untuk Membangun Kemampuan Berpikir Kritis Peserta Didik pada Tema Global Warming. PENDIPA Journal of Science Education, 6(1), 278-284. https://doi.org/10.33369/pendipa.6.1.278284

Pane, A., \& Dasopang, M. D. (2017). Belajar dan Pembelajaran. FITRAH:Jurnal Kajian Ilmu-Ilmu Keislaman, 3(2), 333352. https://doi.org/10.24952/fitrah.v3i2.945

Raab, P., \& Bogner, F. X. (2021). Knowledge acquisition and environmental values in a microplastic learning module: Does the learning environment matter? Studies in Educational Evaluation, 71, 101091. https://doi.org/10.1016/j.stueduc.2021.10 1091

Raiman, M., Liu, A. N. A. M., \& Wolo, D. (2021). Investigation of students' motivation to learn science while studying from home during a pandemic. Journal of Research in Instructional, 1(1), 33-42. https://doi.org/10.30862/jri.v1i1.10

Ritonga, N. (2016). Pengaruh pembelajaran kontruktivisme berbasis CTL (contekstual teaching and learning) terhadap hasil belajar siswa pada materi pencemaran lingkungan di kelas X MAS Alwasliyah Negeri Lama. Jurnal NUKLEUS: Jurnal Pembelajaran Biologi Dan Biologi, 2(1), 1-5. https://doi.org/10.36987/jpbn.v2i1.1212

Rusman, R. (2010). Model-model Pembelajaran. Jakarta: Rajawali Pers. Google Scholar

Ruto, R., Mema, A., Nduru, M. P., \& Ota, M. K. (2021). Contextual teaching and learning approach in social science: its role to encourage pupils' cognitive learning achievement. Journal of Research in Instructional, 1(1), 43-52. https://doi.org/10.30862/jri.v1i1.11 
Suryawati, E., Osman, K., \& Meerah, T. S. M. (2010). The effectiveness of RANGKA contextual teaching and learning on students' problem solving skills and scientific attitude. Procedia - Social and Behavioral Sciences, 9, 1717-1721. https://doi.org/10.1016/j.sbspro.2010.12. 389

Suwarni, K., Dibia, K., \& Renda, N. T. (2013). Penerapan CTL untuk meningkatkan aktivitas dan hasil belajar menulis puisi kelas III SD N 1 Labasari Kecamatan Abang. MIMBAR PGSD Undiksha, 1(1), 1-10. Retrieved from https://ejournal.undiksha.ac.id/index.php/ JJPGSD/article/view/913/783

Syaifuddin, T., Nurlaela, L., \& Perdana, S. (2021). Contextual Teaching and Learning (CTL) Model to Students Improve Learning Outcome at Senior High School of Model Terpadu
Bojonegoro. IJORER: International Journal of Recent Educational Research, 2(5), 528-535. https://doi.org/10.46245/ijorer.v2i5.143

Werimon, S., Damopolii, I., \& Nunaki, J. H. (2017). Pengaruh Model Pembelajaran Stad Dipadu Media Pembelajaran Komik Materi Sistem Pencernaan Manusia Terhadap Hasil Belajar Siswa. Jurnal Eksakta Pendidikan (Jep), 1(2), 33. https://doi.org/10.24036/jep.v1i2.52

Zulaiha, S. (2016). Pendekatan contextual teaching and learning (CTL) dan implementasinya dalam rencana pembelajaran PAI MI. BELAJEA: Jurnal Pendidikan Islam, 1(1), 41-60. https://doi.org/10.29240/bjpi.v1i1.84 